\title{
Information Technology for Travel Agency
}

\author{
E S Soegoto' ${ }^{1}$ A H Nugroho ${ }^{*}$ \\ ${ }^{1}$ Departemen Manajemen, Universitas Komputer Indonesia, Indonesia \\ 2Fakultas Teknik dan Ilmu Komputer, Universitas Komputer Indonesia, Indonesia \\ Email: *adityanugroho@mahasiswa.unikom.ac.id
}

\begin{abstract}
The purposes of this research are to describe, analyze, and determine the online marketing strategy of domestic travel agent at Bandung Tour Expert. In this case, the authors focused on SWOT analysis to find out the right marketing strategy for the tour packaging. In this research, the data was collected using the observation method, meanwhile the data analysis method used were descriptive qualitative and SWOT analysis. Internet users number are increasing, especially adults with high mobility. For them who often travel outside the city, internet is crucial because it connects them with the travel agent. Nowadays, the convenient use of Internet technology is used to market products and services offered by travel agents, so that it provides many benefits for business travel agents with minimum marketing costs. The results of this study were the use of internet and online marketing had impacts on the increasing profits of the travel agents. The conclusion of this research is Bandung Tour Expert as a company need to improve their variant of tour package to make tourist more interest to visit the company website.
\end{abstract}

\section{Introduction}

In the era of globalization, the development of Information Technology (IT) is growing rapidly. IT helps companies to develop and experience rapid growth year by year. The manager of the company chooses to use IT for interacting efficiently and conducting business openly. IT brings companies much closer to consumers, helps reduce the costs, and makes businesses more flexible [1]. Bandung, as one of the tourist destinations in Indonesia and attracts many tourists, has developed many forms of facilities and infrastructure in it. One of them is providing easily accessed tour packages information or booking. Online media can promote these products or services through websites, online advertisements, mailing lists, social networks, blogs, business communities, etc. With the unlimited market range, it will increase the opportunities to attract as many consumers as possible [2]. The use of social media both in web and cellular-based internet technology is to create a variety of unlimited information in any geographical, social, political or demographic aspect through participatory and collaborative public interaction. Social media has now been used by commercial circles and has become a global phenomenon in recent years [3].

Bandung Tour Expert is a travel agency that offers tour packages to consumers or tourists on online media. In conducting its business, Bandung Tour Expert has several products, one 


\section{International Journal of Research and Applied Technology}

1(1)(2021) 148-153

Journal homepage: https://ojs.unikom.ac.id/index.php/injuratech

of them is tour package. A tour package is a series of activities where tourists can choose various activities such as tours and tour packages that have been arranged for a certain price. The price of tour packages, in general, includes all components in the tour, such as transportation, meals, accommodation, guides, and others [4]. All activities arranged well to be a tour package and marketed to individual and group tourists through the internet. The target market segmentation is domestic tourists. By making online travel package orders, customers or tourists do not need to go directly to travel agents but can directly access the internet by opening the website. This internet media was chosen because of the rapid development of information technology affecting the lifestyles of current customers, including the way Bandung Tour Expert Tours market or promote the product and service that has been designed using internet media [5]. Promotion on online media can facilitate consumers and be more efficient for companies [6]. With this information, researchers are interested in knowing how the marketing strategy of travel packages through internet media at Bandung Tour Expert.

The purpose of this research is to describe how marketing strategies on online media affect company positively. Therefore, we will explain how to analyze the marketing strategy carried out by Bandung Tour Expert using SWOT analysis techniques so that all the strengths, weaknesses, opportunities, and threats found in the company can be known.

\section{Method}

In this research, the data collected using observation techniques by making direct observations to the research location for obtaining a clear picture of the tour packages and its marketing. This research used descriptive, qualitative, and SWOT analysis methods to find out the marketing strategy problem variables related to prices, products, promotions, and distribution channels owned by Bandung Tour Expert.

\section{Results and Discussion}

The marketing strategy carried out through internet media by Bandung Tour Expert was a strategy to make customers and tourists access their products and services easily. In marketing their products and services, Bandung Tour Expert used a website as its online media. This website could be accessed by all people wherever they are as long as they had internet access. The influence of internet media in Bandung Tour Expert also affected segmenting, targeting, and positioning. The demographics of product and service sales from Bandung Tour Expert were centered on domestic or domestic tourists only. The target market involved men and women aged from children to adults because the available routes were domestic travel in Bandung. Various tour packages offered enable tourists to have more options and choose attractive tour packages to meet their vacation needs. The followings are the products found on Bandung Tour Expert website.

- Main Menu

In the Main Menu view, there were various sub-menus containing products from Bandung Tour Expert. The main menu appearance was very interesting and user-friendly. The following is the sub-menu package tour, and the order form (see Figure 1). 
International Journal of Research and Applied Technology

1(1)(2021) 148-153

InJURATECH

Journal homepage: https://ojs.unikom.ac.id/index.php/injuratech
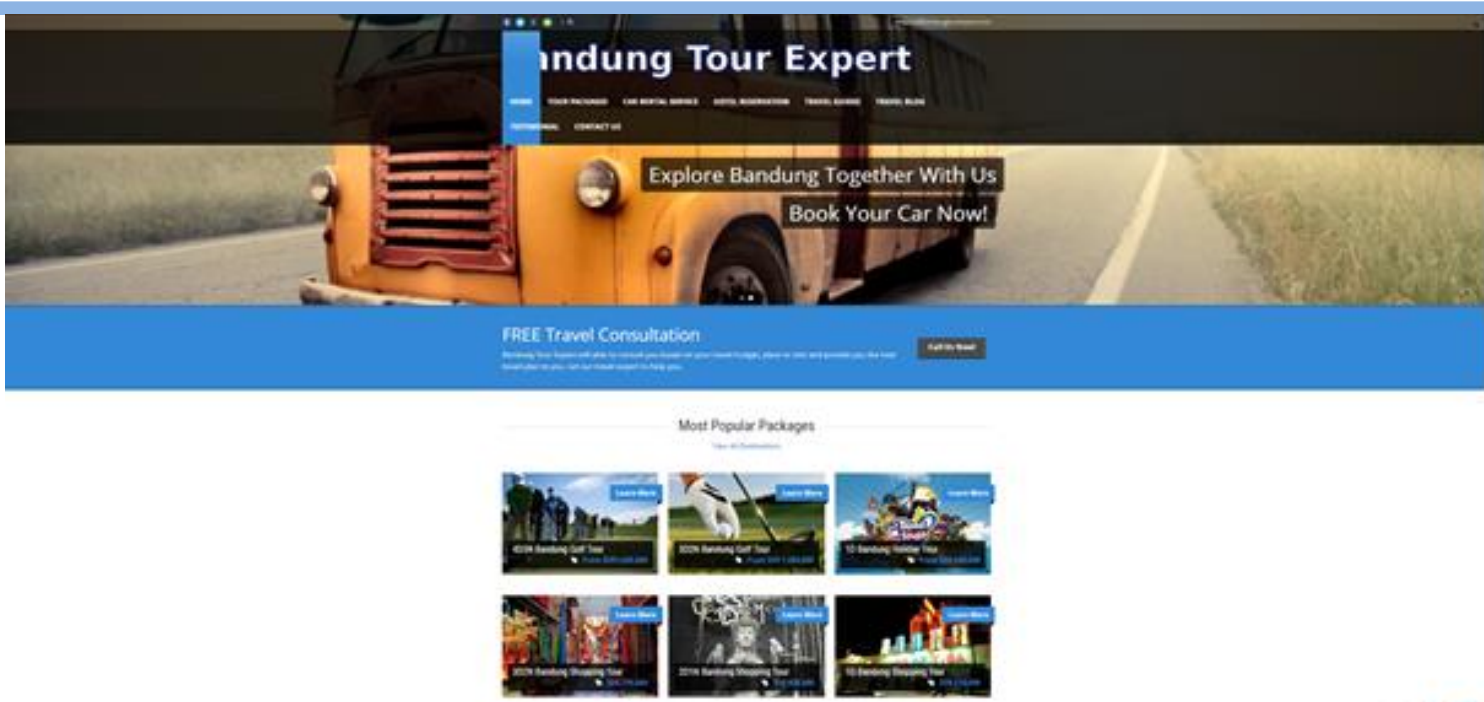

Figure 1. Main Menu

- Package Tour

This Tour Package Menu contained product information such as description of the tour, itinerary, and all product prices (see Figure 2).
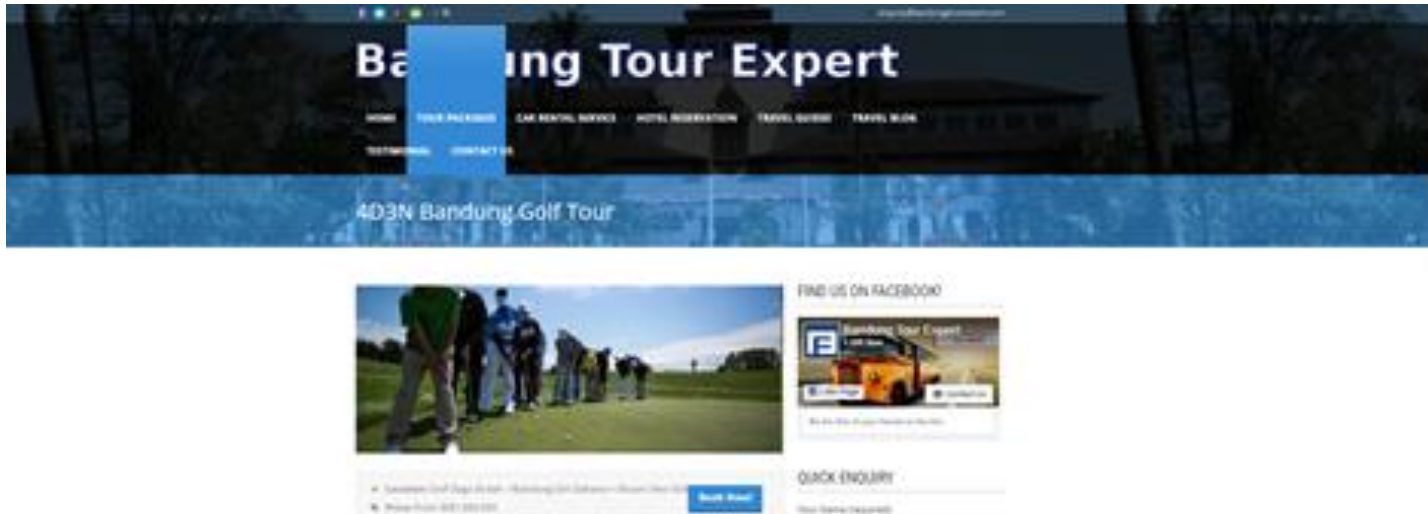

ascrowien

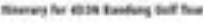

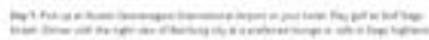

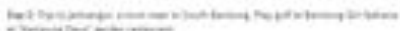

Limen:

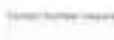

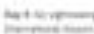

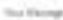

000 우웅

Figure 2. Package Tour 


\section{- Order Form}

In the Order Form Menu, consumers had to entry their name, email, and telephone number to make an order. They can also send message along with it (see Figure 3).

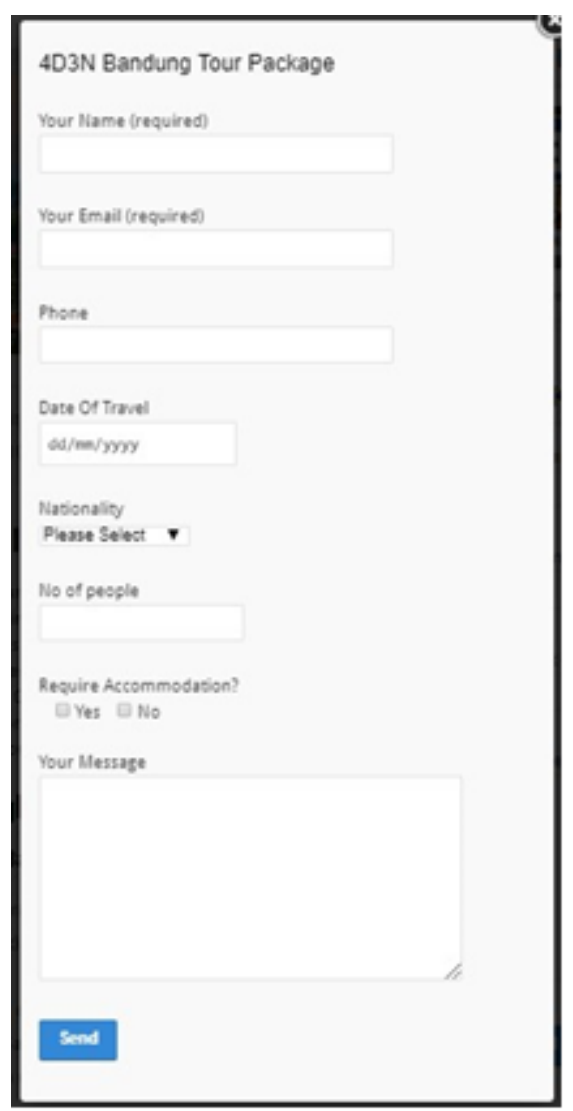

Figure 3. Order Form

Bandung Tour Expert marketed their products through internet media using BTB and BTC. BTB stands for Business to Business which is an activity where Bandung Tour Expert conducted product marketing through internet media by installing several outbound and inbound tour packages that could attract several potential agents abroad to market the these packages in their countries. Business to Business had different prices from the ones on the website. It was also occurred for other collaborated travel agency companies.

On the other hand, BTC or Business to Customer directly corresponded with tourists who bought tour packages. They would be subject to the prices listed on the website. Marketing tour packages through online media were preferable to brochures because it was more efficient for Bandung Tour Expert. Consumers who would buy tour packages could easily access the website. Moreover, the payment system and purchase confirmation were made as convenient as possible. The development of technology was now equal to the rapid growth of travel agents in Bandung which grew rapidly with tight competition. Facing this situation, Bandung Tour Expert continued to improve its strategy to survive and compete with other travel agents. Discussing these problems, SWOT analysis obtained the strengths, weaknesses, opportunities, 
International Journal of Research and Applied Technology

1(1)(2021) 148-153

Journal homepage: https://ojs.unikom.ac.id/index.php/injuratech

and threats in marketing tour packages through online media in Bandung Tour Expert which can be seen in Table 1 .

Table 1. Analysis SWOT

a. The tour packages that were marketed through online media were quite varied.

STRENGTH (S) b. Display images on the website for each tour package were very interesting.

c. Marketing costs incurred were cheaper than using print media

d. Traveling information could be found easily by consumers

e. The website enabled to be accessed worldwide

a. Consumers found it difficult to request special package tours

b. Occasionally consumers complained about the incompatibility offered on

WEAKNESSES (W) the packages with what actually served to them

c. The price of tour packages was in Indonesian Rupiah (IDR)

d. Error system occurred occasionally

a. It took short time to renew or add new tour packages

OPPORTUNITIES $(\mathrm{O}) \quad$ b. Various and interesting tour packages attracted consumers to book a package

c. Tour packages were sold to the specific target

d. The website enabled to be accessed worldwide

a. Business competition got tougher to promote travel packages through online

b. Personal data of consumers were at risk of data misuse for buying package

THREATS (T) online

c. It occasionally had price competition with other travel agents

d. Consumers had low trust due to several online sites that commit fraud

a. Utilizing a variety of packages and attractive travel package to increase the interest of consumers

b. Cheap package prices must be followed by appropriate quality so sales are

Strategy SO on target

c. Increasing promotion through online media so that more consumers access the website

d. Showing complete information about travel packages

a. Giving new options to consumers

Strategy WO b. The information posted on the website must be in accordance with facts

c. Applying excellent internet connection system to prevent error system

a. Making different tour packages and changed the website appearance to be more attractive and optimal

Strategy ST

b. Keeping the personal data confidential to prevent data

c. Providing accurate information from existing facts as they are

Strategy WT

a. Improving the quality of products and services

b. Offering special prices in Indonesian Rupiah for domestic tourists

Based on the results of the research above, it could be described that the marketing of Bandung Tour Expert products was appropriate in choosing internet media as medium for promotion and marketing. The SWOT analysis showed strategies to enhance marketing activity by minimizing and eliminating weaknesses and threats. 


\section{International Journal of Research and Applied Technology}

1(1)(2021) 148-153

Journal homepage: https://ojs.unikom.ac.id/index.php/injuratech

\section{Conclusion}

It can be said that it is appropriate to choose online media as a medium for promotion and marketing of travel packages because it has been proven with SWOT analysis and it showed many internal factors that have a positive impact on the company. The advantages of each strategy that comes from within the company must be improved to reduce the weaknesses and threats of competitors.

\section{Acknowledgement}

This research can be completed in a timely manner thanks to the support of various parties who have made it easy to be able to complete this task..

\section{References}

[1] Soegoto, E. S. 2018. Radio frequency identification (RFID) smart card on parking system as e-business prospect. Journal of Engineering Science and Technology (JESTEC), 13(6), pp.1690-1699.

[2] Soegoto, E. S., \& Utomo, A. T. 2019. Marketing Strategy Through Social Media. In IOP Conference Series: Materials Science and Engineering, 662(3), p. 032040.

[3] Soegoto, E. S., \& Huda, M. N. 2019, November. Utilization of Information Technology as Online Business Marketing Media. In IOP Conference Series: Materials Science and Engineering, 662(3), p. 032018.

[4] Soegoto, E. S., \& Septiawan, H. 2018. Improving SME Marketing in Belitung District through Online Market. In IOP Conference Series: Materials Science and Engineering, 407(1), p. 012043.

[5] Soegoto, E. S., \& Marica, A. 2018. Influence of Internet Marketing on Concert Ticket Purchasing. In IOP Conference Series: Materials Science and Engineering, 407(1), p. 012015.

[6] Rahayu, S. K., \& Fatima, F. N.2019. Marketing Communication Strategy with ECommerce. In IOP Conference Series: Materials Science and Engineering, 662(3), p. 032058.

[7] Gong, T., Li, D., Liu, Y., Wang, G., \& Zhu, H. 2019. Analysis of Marketing Strategy of Electricity Selling Companies in the New Situation. In Journal of Physics: Conference Series, 1187(2), p. 022043.

[8] Hijuzaman, O., \& Rahayu, A. 2018. The effect of green supply chain management implementation to marketing performance through company competitiveness (study on paper industry in West Java). In Journal of Physics: Conference Series , 1013(1), p. 012165.

[9] Azmi, A., \& Adriman, R. 2018. Marketing practitioner's tacit knowledge acquisition using Repertory Grid Technique (RTG). In IOP Conference Series: Materials Science and Engineering , 352(1), p. 012059.

[10] Sarkum, S., Suryadi, S., Munthe, I. R., \& Hidayat, R. 2019. The zoning strategy for smes: a marketing concept $\mathrm{O} 2 \mathrm{O}$ (offline and online). In Journal of Physics: Conference Series , 1175(1), p. 012211. 